\title{
TANTANGAN KEBIJAKAN DIPLOMASI PERTAHANAN MARITIM INDONESIA DALAM PENYELESAIAN KONFLIK LAUT NATUNA UTARA
}

\author{
Ahmad Pradipta Budhihatma Adikara dan Adis Imam Munandar \\ Program Studi Ketahanan Nasional \\ Sekolah Kajian Stratejik dan Global \\ Universitas Indonesia \\ Email: ahmad.pradipta@ui.ac.id, adis.imam@ui.ac.id
}

\begin{abstract}
ABSTRAK
Penelitian ini bertujuan untuk meninjau dan menganalisis bentuk pelaksanaan dan tantangan dari diplomasi pertahanan maritim yang dilaksanakan Pemerintah Indonesia. Melalui metode kualitatif dengan menggunakan pendekatan narrative policy analysis, penelitian ini memperlihatkan bentuk dan tantangan kebijakan diplomasi pertahanan maritim sebagai strategi kebijakan yang dilakukan untuk menjaga kedaulatan sektor maritim Indonesia terutama yang ada di perbatasan berdasarkan struktur naratif dan simbolik yang ada dalam proses kebijakan. Hasil penelitian ini menunjukkan kebijakan diplomasi pertahanan maritim masih belum maksimal karena pertama kerjasama bilateral dan multilateral tidak dilakukan dengan negara yang terlibat konflik secara langsung dengan Indonesia, kedua belum adanya koordinasi antar instansi terkait dalam penerapan kebijakan diplomasi pertahanan maritim Indonesia. Hal tersebut dibuktikan dengan masih banyak terjadi insiden penangkapan kapal asing terutama dari Tiongkok di wilayah perairan Laut Natuna Utara.
\end{abstract}

Kata Kunci: Diplomasi Pertahanan Maritim, Indonesia, Kebijakan, Laut Natuna Utara, Tiongkok

\section{ABSTRACT}

This study aims to review and analyze the forms of implementation and challenges of maritime defense diplomacy carried out by the Government of Indonesia. Through a qualitative method using approach narrative policy analysis, this study shows the forms and challenges of maritime defense diplomacy as a policy strategy to safeguard the sovereignty of the Indonesian maritime sector, especially those on the border based on the narrative and symbolic structures in the policy process. The results of this study indicate that the maritime defense diplomacy policy is still not optimal because first, bilateral and multilateral cooperation are not carried out with countries that are directly involved in conflict with Indonesia, secondly there is no coordination between related agencies in the implementation of Indonesia's maritime defense diplomacy policy. This is evidenced by the many incidents of catching foreign vessels, especially from China, in the waters of the North Natuna Sea.

Keywords: Maritime Defense Diplomacy, Policy, Indonesia, North Natuna Sea, Tiongkok 


\section{PENDAHULUAN}

Wilayah Indonesia yang terdiri dari beberapa pulau dan mayoritas adalah lautan, menjadikan Indonesia sebagai negara maritim. Banyaknya wilayah perbatasan Indonesia yang berupa lautan, membuat Indonesia harus memiliki kekuatan armada yang memadai untuk menjaga keamanan maritimnya di perbatasan. Beberapa waktu terakhir Laut Natuna Utara yang menjadi ujung perbatasan Indonesia terlibat konflik oleh beberapa negara yang mencoba menerobos masuk wilayah perbatasan Indonesia. Wilayah Laut Natuna Utara menjadi perbincangan di dunia internasional karena sarat dengan nilai strategis. Nilai strategis yang terdapat dalam Laut Natuna Utara adalah Sumber daya alam yang terkandung di dalamnya seperti minyak bumi dan gas alam. Selain itu perairan Natuna Utara juga memiliki peran penting dalam jalur distribusi pedagangan, dan pelayaran internasional.

Hegemoni Tiongkok dan Amerika Serikat di kawasan Asia Tenggara menghadirkan kondisi baru dalam pergerakan di wilayah perbatasan Laut Natuna Utara. Aspek pertahanan menjadi pemain utama dalam pengamanan alur Laut Kepulauan Indonesia. Potensi ancaman yang selalu hadir dalam wilayah yang menjadi jalur pelayaran membuat Presiden Joko Widodo mencanangkan visi dalam bidang kemaritiman pada tahun 2014 yang menjadikan Indonesia sebagai Poros Maritim Dunia dengan mengembalikan kejayaan Indonesia di sector maritim. Pilar yang menjadi poin utama adalah pilar pertahanan, keamanan, penegakkan hukum, dan keselamatan laut (Mundayat dan Widodo 2018, Hal 23).

Beberapa bentuk ancaman yang terjadi di perbatasan Laut Natuna Utara antara lain klaim dan tumpang tindihnya wilayah Zona Ekonomi Eksklusif (ZEE) Indonesia yang sudah ada dalam UU No 1 Tahun 1973 tentang Landasan Kontinen Indonesia dengan Nine Dash Line (Sembilan garis putus-putus) milik Tiongkok yang diklaim sepihak. Adanya klaim sepihak dari Tiongkok menyebabkan banyaknya insiden yang terjadi di wilayah perairan Natuna Utara. Dalam penelitian sebelumnya yang dilakukan oleh Kusuma, Halkis, dan Yusgiantoro (2019), menekankan pada pelaksanaan latihan Puncak Angkasa Yudha TNI AU sebagai bentuk diplomasi pertahanan berdasarkan konflik yang terjadi dalam Laut Natuna Utara seperti masuknya kapal penangkap ikan milik Tiongkok ke wilayah kedaulatan Indonesia, dan dilakukan beberapa penangkapan kapal tersebut seperti pada 19 Maret 2016 ketika KM Kway Fey 10078 tertangkap di perairan Natuna yang diduga sedang menangkap ikan secara illegal. Proses penangkapan KM tersebut dihalanghalangi oleh Chinese coast guard naval ship. Saragih (2018) dalam penelitiannya memaparkan upaya diplomatic Indonesia dari perspektif pertahanan Indonesia. Usaha diplomatik Indonesia dalam penyelesaian konflik di Laut Tiongkok Selatan menjadi fokus dalam penelitiannya, seperti banyaknya kapal asing yang masuk ke dalam wilayah teritorial membuat Indonesia tidak boleh tinggal diam karena perairan tersebut merupakan pilar penting bagi kegiatan ekspor impor Indonesia dan jalur perdagangan internasional. Wibawati, Sari, dan Sulistyani (2018), dalam penelitiannya fokus pada potensi dan tantangan dari one be/t one road (OBOR) Tiongkok yang berpengaruh bagi kepentingan nasional Indonesia di bidang maritim. 
Adanya OBOR memicu konflik yang terjadi di Laut Natuna Utara karena menciptakan efek borderless bagi setiap negara yang dilalui oleh Tiongkok.

Pemberian nama Laut Natuna Utara pun juga menjadi salah satu strategi yang dilakukan Pemerintah Indonesia untuk mengklaim wilayah ZEE Indonesia (Muhaimin, 2018). Pada tahun 2017 dibawah arahan Presiden Joko Widodo, Pemerintah Indonesia melakukan pembenahan peta baru wilayah Indonesia dan memperjelas batas wilayah laut dengan memberikan nama Laut Natuna Utara sebagai wilayah laut yang berbatasan langsung dengan Laut Tiongkok Selatan (LTS) (Sambogo, 2018). Kebijakan tersebut dipengaruhi oleh keberanian dan keberhasilan Filipina dalam menggugat Tiongkok mengenai sengketa LTS di Mahkamah Arbitrase Internasional. Keputusan mengenai pembaharuan peta nasional dilaksanakan setelah terjadi kesepakatan antara Indonesia, Singapura, dan Filipina mengenai batas wilayah ZEE ketiga negara. Berdasarkan kesepakatan tersebut yang menjadi landasan hukum, Pemerintah Indonesia berani untuk memberi nama Laut Natuna Utara. Pengubahan peta wilayah batas laut dan pemberian nama Laut Natuna Utara sudah didaftarkan Pemerintah Indonesia ke International Hydrographic Organization (IHO) untuk memperjelas landasan hukum dan hak berdaulat Indonesia demi menjaga keamanan Indonesia di Natuna Utara (Reuters, 2017). Penamaan Laut Natuna Utara sebagai wilayah yang berbatasan langsung dengan LTS tidak bisa dianggap sepele karena dengan adanya penamaan tersebut dapat menunjukkan siapa yang berkuasa atas wilayah tersebut dan menjadi penegas kepemilikan wilayah tersebut.

Kebijakan diplomasi pertahanan maritim menjadi salah satu cara dari pihak Indonesia untuk mengakomodasi kepentingan nasional bidang pertahanan di forum internasional yang dapat diwujudkan dengan kerja sama pertahanan agar wilayah kedaulatan Indonesia yang sudah tercatat dalam konstitusi negara tidak diklaim sepihak oleh negara lain. Dalam beberapa penelitian sebelumnya, tidak dijelaskan secara detail mengenai pola dan tantangan dari kebijakan diplomasi pertahanan maritim Indonesia untuk menyelesaikan permasalahan yang ada di Laut Natuna Utara. Faktanya hingga saat ini wilayah Laut Natuna Utara masih sering terjadi insiden penangkapan kapal asing terutama dari Tiongkok (CSIS, 2017).

Sifat ancaman dalam isu pertahanan dan keamanan negara saat ini bukan hanya bersifat state atau negara, melainkan ancaman individu atau human threat yang bersifat transboundary. Sifat dari keamanan sudah tidak lagi sebatas keamanan negara, melainkan juga keamanan individu atau human security. Keamanan non tradisional saat ini menjadi isu yang berkembang di seluruh negara dunia. Dalam keamanan non tradisional terdapat strategi yang digunakan untuk menghadapi potensi ancaman yang datang, salah satunya adalah diplomasi pertahanan maritim. Menurut Nugraha \& Sudirman (2018), Diplomasi pertahanan maritim adalah istilah yang berlaku untuk berbagai macam kegiatan di wilayah maritim atau perairan dalam hal ini gugus tugas utamanya ada pada Angkatan Laut suatu negara berdaulat. Pada masa damai diplomasi maritim ini dilakukan untuk mempengaruhi perilaku dari negara lain dalam konteks interaksi dan transaksi yang terjadi di wilayah perairan. 
Banyak yang memandang bahwa diplomasi pertahanan maritim disebut sebagai diplomasi militer, tetapi secara prakteknya diplomasi pertahanan adalah sebuah operasi tanpa penggunaan kekerasan dari apparat pertahanan negara untuk memajukan tujuan strategis pemerintah melalui kerjasama dengan negara lain (Winger, 2014). Konsep diplomasi pertahanan dengan diplomasi pertahanan maritim sesungguhnya sama, namun yang membedakan ada pada lingkup strategisnya. Jika diplomasi pertahanan adalah konsep umum, dan penambahan kata maritim dibelakangnya adalah bentuk lingkup dari diplomasi pertahanan tersebut yaitu berada di wilayah lautan. Terdapat beberapa aktivitas diplomasi pertahanan maritim menurut Cottey dan Forster (2004), antara lain kontak bilateral dan multilateral antara pejabat senior militer dan pertahanan sipil, penunjukan atase pertahanan untuk negara asing, perjanjian kerjasama pertahanan bilateral, pelatihan personel pertahanan sipil dan militer asing, penyediaan keahlian dan nasihat tentang kontrol demokratis atas angkatan bersenjata, manajemen pertahanan dan militer area teknis, kontak dan pertukaran antara personel dan unit militer, dan kunjungan kapal, penempatan personel militer atau sipil di kementerian pertahanan dan angkatan bersenjata negara mitra, penempatan tim pelatihan, penyediaan peralatan militer dan bantuan material lainnya, latihan militer bilateral atau multilateral untuk melatih murid.

Diplomasi pertahanan maritim tidak termasuk operasi militer, tetapi mempromosikan bentuk kerjasama seperti: pertukaran personel, kapal dan pesawat, kunjungan tingkat tinggi dan komandan senior, pertemuan dan dialog bilateral, pelatihan dan latihan, forum pertahanan regional, militer bantuan, langkahlangkah membangun kepercayaan dan non-proliferasi (Drab, 2018). Selain itu pemahaman mengenai diplomasi pertahanan maritim didefinisikan oleh Pedrason, Kurniawan, dan Purwasandi (2016) bahwa diplomasi pertahanan maritim sebagai keseluruhan strategi yang dilakukan negara, yang mungkin sedang dalam kompetisi dengan negara lain, untuk membangun kepercayaan melalui praktik kerjasama ekonomi, budaya, politik, pertahanan serta diplomasi itu sendiri.

Aktivitas diplomasi pertahanan maritim terbagi menjadi tiga model yaitu diplomasi petahanan untuk confidence building measures, diplomasi pertahanan untuk capacity building, dan diplomasi pertahanan untuk industri pertahanan (Mundayat dan Widodo, 2018). Terdapat empat jenis tindakan praktek diplomasi pertahanan maritim, antara lain communication, constrains, transparency, dan verification. Selain itu menurut Saragih (2018), Diplomasi pertahanan maritim juga merupakan sebuah proses yang tidak hanya melibatkan aktor negara saja (seperti politisi, kekuatan bersenjata atau badan intelijen), namun juga organisasi non-pemerintah, think tank dan masyarakat sipil. Di Asia Tenggara terdapat empat pola kerjasama keamanan, antara lain pola kerjasama pertahanan multilateral antara external powers dan negara Asia tenggara, kedua ola kerja sama pertahanan yang dipimpin Amerika Serikat, ketiga pola kerja sama pertahanan yang dipimpin Tiongkok, keempat, pola kerjasama multilateral dengan ASEAN sebagai pusatnya. Tujuan utama diplomasi pertahanan maritim adalah untuk membangun dan 
memelihara kepercayaan dan bantuan dalam pengembangan angkatan bersenjata yang demokratis dan memberikan kontribusi yang signifikan untuk pencegahan dan resolusi konflik (Drab, 2018). Kerja sama internasional dikembangkan sebagai salah satu instrumen diplomasi pertahanan maritim dalam mewujudkan kepentingan nasional di bidang pertahanan yang akan diefektifkan melalui langkah-langkah konkret dan saling menguntungkan dalam satu jembatan bagi terwujudnya stabilitas keamanan kawasan (Kementerian Pertahanan, 2015).

Berdasarkan uraian situasi di atas, artikel ini berupaya untuk meninjau dan menganalisis bentuk diplomasi pertahanan maritim yang dilaksanakan Pemerintah Indonesia dan tantangannya dalam pelaksanaan kebijakan tersebut untuk menjaga wilayah kedaulatan Indonesia dengan menggunakan metode kualitatif dan pendekatan narrative policy analysis.

\section{METODE PENELITIAN}

Metode penulisan yang digunakan dalam makalah ini ialah dengan menggunakan metode penulisan kualitatif. Metode penulisan kualitatif adalah penulisan yang ada karena adanya perubahan paradigm dalam memandang suatu realitas, fenome dan gejala. Menurut Creswell (2014), penulisan kualitatif merupakan metode-metode untuk mengeksplorasi dan memahami makna yang oleh sejumlah individu atau sekelompok orang dianggap berasal dari masalah sosial atau kemanusiaan.

Pada penelitian ini, penulis menggunakan teknik pengumpulan data dengan metode Studi Pustaka. Studi Kepustakaan merupakan kajian literatur yang berkaitan dengan budaya, nilai, dan norma yang berkembang secara social dalam pengumpulan datanya menggunakan materi yang ada di dalam perpustakaan seperti buku, majalah, dokumen, dan lain-lain (Sugiyono, 2012). Pendekatan yang digunakan dalam penelitian ini untuk menganalisis sebuah masalah adalah dengan menggunakan Narrative Policy Analysis. Narrative policy analysis merupakan sebuah konsep yang mendasari narasi kebijakan yang dibangun oleh para pemangku kebijakan untuk mempengaruhi kebijakan public secara strategis. Komponen yang digunakan dalam narrative policy analysis menurut Shanahan, Jones, dan McBeth (2017) adalah, pertama narasi kebijakan harus memiliki setidaknya satu karakter, kedua narasi kebijakan juga harus mengacu pada kebijakan kepentingan publik. Terdapat tiga level analisis dalam Narattive Policyyaitu mikro, meso, dan makro. Pada level mikro, focus penelitian pada pengaruh yang dimiliki oleh narasi individu berdasarkan preferensinya terhadap pengambilan keputusannya secara individu. Pada level meso, focus penelitian pada pembangunan narasi kebijakan oleh kelompok dan efek dari narasi kebijakan terhadap proses kebijakannya. Pada level makro, focus penelitiannya tentang kondisi di mana narasi tingkat makro (secara budaya dan institusi politik atau negara) berkembang dan berubah. Penelitian ini menggunakan level analisis makro karena analisis tingkat makro berpusat pada narasi kebijakan yang menembus norma- 
norma negara, lembaga, masyarakat, dan budaya. Proses dalam menentukan kebijakan adalah tindakan yang dilandaskan aktivitas intelektual yang bersifat politis.

Narrative Policy Analysis memiliki elemen naratif yang berusaha mendefinisikan permasalahan (Jones dan McBeth, 2010). Elemen naratif memaknai karakter yang dimasukkan dalan sebuah analisis seperti pahlawan (hero), penjahat (Villain), dan korban (Victim). Karakter tersebut digunakan untuk mengidentifikasi solusi yang dibentuk oleh nilai moralnya. Menurut Jones dan McBeth (2010), dalam narrative policy analysis mayoritas karya yang dihasilkan mengikuti pendekatan kualitatif dan poststruktural dengan berfokus pada teori dan data yang ditemukan.

Tabel 1. Bentuk Elemen Naratif dari Narrative Policy Analysis dan penjelasannya.

\begin{tabular}{|l|l|}
\hline \multicolumn{1}{|c|}{ Elemen Naratif } & \multicolumn{1}{c|}{ Penjelasan } \\
\hline Karakter: Hero, Villains, Victims & $\begin{array}{l}\text { Pihak yang menyelesaikan masalah, pihak yang } \\
\text { menyebabkan masalah, korban. }\end{array}$ \\
\hline Plot: Organizes action & Terstruktur dari awal, tengah, dan akhir. \\
\hline Policy Solution & Moral dan solusi dari cerita dan kebijakan. \\
\hline
\end{tabular}

Sumber: Shanahan, Elizabeth A., Jones, Michael D., McBeth, Mark K. (2017). How to conduct a Narrative Policy Framework study. The Social Science Journal.

\section{PEMBAHASAN}

\section{Pola Kebijakan Diplomasi Pertahanan Maritim Indonesia}

Diplomasi Pertahanan menjadi popular dalam beberapa tahun terakhir terutama di wilayah benua Asia-Pasifik. Australia menjadi pencetus dan memiliki sejarah panjang dalam melakukan diplomasi pertahanan, inventarisasi akan menjadi langkah pertama untuk mengembangkan strategi yang jelas untuk diplomasi pertahanan Australia dan tempatnya dalam kebijakan strategis nasional Australia (Taylor, 2014). Sejak tahun 1950an Australia sudah menerapkan diplomasi pertahanan ke wilayah Asia Tenggara dan Pasifik Barat Daya. Salah satu daya tarik mengapa Australia menggunakan metode diplomasi pertahanan, adalah bahwa hal tersebut menyediakan cara yang tidak begitu kontroversial untuk bekerja sama dalam masalah keamanan daripada metode diplomasi tradisional (Bisley, 2014). Diplomasi pertahanan dianggap dapat mengurangi ketegangan dan membantu mengelola krisis dalam sebuah negara. Sebagai contohnya selama tahun 1960-an dan 1970-an, Australia memberikan bantuan pertahanan yang cukup besar kepada negaranegara di wilayah Asia Tenggara dan pasifik Barat Daya dengan tujuan untuk memajukan kepentingan strategis di kawasan tersebut terutama di wilayah laut Samudera Hindia. Kemudian, inventarisasi diplomasi pertahanan Australia dapat menjelaskan alasan mengapa praktek terebut bertahan lama dan berjalan baik. 
Jurnal Studi Diplomasi dan Keamanan, Volume 13. No 1, January 2021.

Salah satu program diplomasi pertahanan yang menurut Taylor (2014) dapat bertahan hingga saat ini adalah Program Beasiswa Kerjasama Pertahanan. Di bawah program ini, dana disediakan untuk mendukung sekitar 70 pejabat asing selama mereka belajar di Australia. Beasiswa tersebut dilakukan di berbagai universitas di Australia dengan program studi yang bermacam-macam seperti, Teknik, Hubungan Internasional, Hukum dan Kebijakan Hak Asasi Manusia, Studi Strategis, Pendidikan dan Teknologi Informasi.

Pada tahun 1952, Australia dengan Thailand juga sempat melakukan hubungan diplomatik bidang pertahanan dan keamanan kawasan yang mana dahulu Thailand merupakan Organisasi Perjanjian Asia Tenggara (SEATO) yang sekarang sudah tidak berfungsi. Setelah itu, sebagai investasi dalam hubungan tersebut, Australia secara rutin berpartisipasi dalam serangkaian latihan militer bilateral yang dirancang untuk mendorong saling pengertian dan interoperabilitas yang lebih besar untuk berbagai kemungkinan. Latihan udara, darat, laut, dan pasukan khusus semacam itu memberikan peluang untuk memelihara saluran komunikasi serta tolok ukur yang penting untuk mengetahui kemampuan satu sama lain. Di Pasifik Selatan, Australia juga menjalin hubungan diplomasi pertahanan dengan Papua Nugini (Blaxland, 2014). Pertukaran rutin, pelatihan dan latihan bersama serta berbagai kepentingan bersama terus membina hubungan bilateral dengan PNG Defense Force (PNGDF). Di Asia sendiri, Australia telah terlibat dalam diplomasi pertahanan baik secara bilateral maupun multilateral selama lebih dari dua puluh tahun. Australia telah melakukan bentuk diplomasi pertahanan dengan negara-negara di Asia antara lain seperti Dialog ShangriLa yang dikelola IISS, ADMM +, latihan RIMPAC, dan Simposium Angkatan Laut Pasifik Barat (Bisley, 2014). Hal tersebut dilakukan untuk mendapatkan keamanan Asia yang lebih luas dan dinamis dengan tetap mementingkan investasi dalam kebijakan strategis jangka panjang.

Situasi yang sama juga dihadapi oleh Indonesia dalam menjaga wilayah kedaulatan dan kepentingan strategisnya. Secara khusus, Indonesia banyak belajar dengan Australia dalam hal Diplomasi Pertahanan, dan kedua negara tersebut sempat melakukan kerjasama diplomasi pertahanan. Menurut Pramitha (2017), Indonesia memiliki focus bersama dengan Australia dibidang keamanan yang bersifat eksternal yaitu, bidang keamanan maritim di wilayah Samudera Hindia untuk menjaga stabilitas keamanan di wilayah Samudera Hindia melalui forum Indian Ocean Rim Association (IORA). Praktek diplomasi pertahanan kemudian dilakukan oleh Pemerintah Indonesia dan digunakan dalam kebijakan strategis nasional terutama dalam menjaga wilayah kedaulatannya. Kedaulatan teritorial Indonesia harus menjadi kepentingan utama dan vital dalam menentukkan kebijakan luar negeri dan pertahanan. Berdasarkan buku putih pertahanan Indonesia tahun 2015, kebijakan strategis pembangunan nasional yang tertuang dalam RPJPN Tahun 2005-2025 mengarahkan pertahanan negara pada membangun postur pertahanan yang tangguh dan memiliki kekuatan penangkalan sebagai negara kepulauan dalam mendukung kebijakan poros 
maritim dunia. Adanya sengketa kasus Laut Natuna Utara yang masih berjalan hingga saat ini dapat menjadi pertimbangan kebijakan kawasan karena bersinggungan langsung dengan kepentingan utama tersebut.

Pada tanggal 17 Juni 2016, sebuah kapal korvet kecil Angkatan Laut Indonesia, KRI Imam Bonjol, menghadapi setidaknya tujuh kapal nelayan dan dua Kapal Pengawas Pantai Tiongkok (Chinese Coast Guard) yang jauh lebih besar di Zona Ekonomi Eksklusif (ZEE) Indonesia dekat Kepulauan Natuna yang terpencil (Lowy Institute, 2016). Dalam mengatasi sengketa kasus Laut Natuna Utara, Indonesia harus memahami posisi negara lain yang terlibat dalam sengketa wilayah tersebut. Integrasi negara ASEAN menjadi prioritas dalam menyelesaikannya. Karena dengan kondisi ini memungkinkan Tiongkok dan beberapa negara ASEAN secara unilateral mengklaim memiliki kedaulatan atau hak berdaulat atas wilayah maritim yang dipersengketakan tersebut (Laksmana, Gindarsah, dan Mantong, 2018). Diperlukan kebijakan strategis yang mampu menyelesaikan konflik Laut Natuna Utara tanpa harus terlibat konflik dengan negara lain. Strategi kebijakan pertahanan dalam menjaga wilayah kedaulatan teritorial yang digunakan Pemerintah Indonesia dan bersifat soft defense adalah dengan menggunakan diplomasi pertahanan maritim. Kebijakan tersebut digunakan karena ada penekanan dari internasional tentang kebijakan pertahanan nasional di negara-negara seluruh dunia telah bergeser dari pencegahan menuju pada keamanan kooperatif teritorial, yang mana salah satu caranya adalah dengan diplomasi pertahanan maritim (The Strategic Survey, 2019).

Seiring dengan perubahan dan perkembangan jaman, negara-negara Asia Tenggara kini mampu menggunakan diplomasi pertahanan untuk mencapai dua kepentingan yang selama ini dikenal saling bersilangan yaitu, pembangunan nasional dan keamanan nasional (Midhio \& Priyono, 2019). Menurut Fearon (2002), peluang akan dimenangkan menuju politik internasional oleh mereka yang mampu bermain secara elegan dengan sumber domestic yang tersedia. Berdasarkan hal tersebutlah membuat Indonesia sangat meyakini bahwa diplomasi pertahanan maritim merupakan wahana dan sarana yang komprehensif untuk memperjuangkan kepentingan dalam negeri seperti menjaga wilayah kedaulatan dengan memanfaatkan kepentingan di luar negeri. Seperti diketahui, saat ini Pemerintah Indonesia lebih menggunakan konsep dari Diplomasi Pertahanan Maritim, karena dinilai lebih jelas, soft, dan spesifik dalam penerapan kebijakannya. Penggunaan diplomasi pertahanan maritim tidak hanya melibatkan militer, tetapi sipil ikut andil dalam perannya, bahkan lebih besar peran yang dimainkan.

Diplomasi pertahanan maritim memang memainkan peran penting dalam membentuk dan melaksanakan kebijakan keamanan di banyak negara yang mana sebagai instrumen khusus kebijakan luar negeri mereka dan menempati tempat permanen dalam sistem kerja sama antara negara dan organisasi internasional (Drab, 2018). Seperti contohnya di Prancis, kerja sama militer dan pertahanan berada di bawah kendali Direktorat Kerja Sama dan Pertahanan Militer di Kementerian Luar Negeri (DCSD, Directorate of Cooperation of Security and Defence), sedangkan pengawasan jaringan pertahanan diplomatik bilateral di 
kedutaan Prancis berada di bawah Departemen Hubungan Internasional dan Strategis. (DGRIS, Direction Générale des Relations Internationales et de la Stratégie) di Kementerian Pertahanan, yang terakhir dijalankan oleh seorang diplomat tetapi dengan personel militer konsentrasi tinggi (Charillon, Balzacq, \& Ramel, 2020).

Terdapat tiga pola yang digunakan Pemerintah Indonesia dalam melakukan diplomasi pertahanan maritim untuk menyelesaikan sengketa yang ada dalam Laut Natuna Utara. Pola yang digunakan antara lain, Diplomasi Pertahanan Maritim Bilateral, Diplomasi Pertahanan Maritim Multilateral, dan Diplomasi Pertahanan Maritim Hukum Internasional. Pada bagian ini, penulis mencoba memaparkan bentuk dan contoh langsung dari ketiga pola diplomasi pertahanan maritim Indonesia.

Pertama adalah Diplomasi Pertahanan Maritim Bilateral. Perjanjian bilateral ini adalah bagian dari diplomasi pertahanan Indonesia yang bertujuan meningkatkan pembangunan kepercayaan sambil memperkuat kapabilitas pertahanan di tengah ketidakpastian situasi kawasan (CSIS, 2017). Tipe dari diplomasi pertahanan maritim bilateral dilakukan berdasarkan faktor kepentingan maritim dari kedua negara. Bentuk dari diplomasi pertahanan maritim bilateral antara lain seperti pertukaran informasi intelijen bidang keamanan maritim, patroli bersama, dan latihan bersama. Selain itu investasi dalam hubungan regional bilateral melalui beasiswa Pendidikan militer, pertukaran dan latihan dapat menghasilkan serangkaian pembagian jangka pendek dan jangka panjang yang mengejutkan dalam hubungan pribadi antar negara dan kemauan untuk bekerja sama dalam tugas-tugas operasional yang mendatang (Blaxland, 2014).

Bentuk diplomasi pertahanan maritim bilateral yang dilakukan oleh Pemerintah Indonesia adalah, bulan Desember 2019 Menteri Pertahanan Indonesia melakukan perjanjian kerja sama pertukaran informasi intelijen dengan Australia (Kementerian Pertahanan, 2019). Dalam kerja sama tersebut Indonesia dan Australia sepakat untuk memerangi penangkapan ikan secara illegal dan kejahatan trans-nasional. Kemudian Panglima TNI dalam Forum Asean Chiefs of Defence Forces Melting pada bulan September 2020 mengusulkan kerja sama militer dengan negara-negara ASEAN, salah satunya adalah pertukaran informasi intelijen (Mabes TNI, 2020). Pada bulan Oktober 2018 delegasi Indonesia dan Fillipina meninjau kembali perjanjian patroli perbatasan dan pelintas batas tahun 1975 dalam sidang ke-38 Komite Perbatasan Indonesia-Filipina di Auditorium Puslat Kaprang, Koarmada II, Surabaya (Mabes TNI, 2018). Dalam sidang perjanjian kedua negara tersebut mempertimbangkan pelibatan aparat penegak hukum sipil di bidang maritim dalam pelaksanaan patroli terkoordinasi. Selanjutnya pada bulan Oktober 2020, TNI AL menggelar latihan bersama dengan Kapal Perang Pasukan Beladiri Jepang (JMSDF) di ZEEI Barat daya Pulau Jemaja hingga keluar dari perairan Natuna Utara (Kompas, 2020). Latihan bersama tersebut dilakukan untuk meningkatkan kerja sama dengan negara lain dengan melakukan peran diplomasi pertahanan maritim dengan menggunakan metode passing exercise. Indonesia juga berminat untuk bergabung dengan latihan 
perang gabungan dengan Amerika Serikat di wilayah ini. Sudah dua kali latihan dilakukan bersama AS di Batam yang berjarak $480 \mathrm{~km}$ dari Natuna (Saragih, 2018). Indonesia sebelumnya juga pernah melakukan diplomasi pertahanan maritim dengan Malaysia dalam kasus selat malaka dengan menerapkan strategi diplomasi yang dilakukan dengan $\mathrm{G}$ to $\mathrm{G}$ (Government to Government). Strategi tersebut dilakukan dengan menggunakan instrumen diplomasi pertahanan dan kebijakan luar negeri untuk mewujudkan kepentingan nasional dan menjaga kedaulatan setiap negara yang berlangsung secara bilateral dan secara multilateral (Fathun, 2019). Hal tersebut juga dapat dilakukan kembali oleh Pemerintah Indonesia dengan Malaysia untuk menyelesaikan konflik yang ada di Laut Natuna Utara.

Kedua adalah diplomasi pertahanan maritim multilateral. Perjanjian ini kurang lebih sama dengan perjanjian bilateral, yang membedakan adalah perjanjian multilateral melibatkan lebih dari 2 negara yang melakukan perjanjian. ASEAN hingga tahun 1994, tidak ada upaya multilateral negara untuk mengatasi banyak tantangan keamanan di kawasan ini. Paska tahun tersebut banyak negara Asia menganggap diplomasi pertahanan sebagai bentuk yang paling berguna dan efektif dari gelombang multilateralisme keamanan baru-baru ini di kawasan, dan Diplomasi pertahanan dalam hubungan multilateral dianggap berpotensi untuk mengelola ketegangan, meningkatkan arus informasi, dan membangun kepercayaan dan kesamaan tujuan di Asia (Bisley, 2014). Bulan Juni 2017, Indonesia, Malaysia, dan Filipina menandatangani kerja sama patroli (Kementerian Pertahanan, 2017). Kerja sama tersebut dilakukan untuk memperkuat dan mengkoordinasikan patroli pada masing-masing daerah maritim dari tiga negara. Kerja sama yang dilakukan antara lain peningkatan komunikasi dan pertukaran informasi intelijen, patroli bersama, dan percepatan penempatan asset angkatan laut sebagai respon cepat terhadap keadaan bahaya. Dalam buku Diplomasi Pertahanan Maritim: Strategi, Tantangan, dan Prospek (CSIS, 2017) tertulis Indonesia semakin berusaha meningkatkan partisipasinya di berbagai forum diplomasi pertahanan maritim multilateral nonASEAN, meski dalam skala yang jauh lebih kecil. Indonesia mencoba pendekatan multilateralisme, menyarankan 'dewan bersama' untuk kerja sama pertahanan dan latihan militer bersama di antara negaranegara Asean tetapi konsensus KTT Aseam menolak untuk melembagakan pertimbangan keamanan di dalam Asean (Manowong dan Ocha, 2017).

Kerjasama multilateral bidang pertahanan di ASEAN terdapat dalam forum yang bernama Asean Defence Ministers Meeting Plus (ADMM+), yang mana forum tersebut dapat digunakan sebagai langkah diplomasi pertahanan maritim multilateral (Tan, 2014). ADMM+, didirikan sebagai upaya untuk memperkuat kerjasama pertahanan dan keamanan dengan tiga level, pertama mempromosikan kerja praktis tingkat operasional, kedua keterlibatan ASEAN dengan non-ASEAN dalam isu nontradisional dan lintas batas, ketiga memperkuat sentralitas dalam rencana keamanan di Asia Tenggara (Gilang P, 2016). Terkait dengan kepentingan Indonesia, ADMM + telah melakukan sejumlah inisiatif regional, termasuk kolaborasi industri pertahanan, jaringan pusat penjaga perdamaian, dan dukungan logistik untuk misi keamanan non- 
tradisional dan tak kalah pentingnya, baru-baru ini mereka menyerukan pembentukan tautan komunikasi langsung untuk pertukaran informasi jika terjadi krisis (Gandarsih, 2015).

Kerjasama multilateral lainnya diselenggarakan oleh Network of ASEAN Defence and Security Institutions (NADI), yang terdiri dari lembaga think tank dan lembaga penelitian, untuk mendukung ADMM (Chang, 2016). Dokumen Pusat Pengkajuan dan Pengembangan Kebijakan Pada Organisasi Internasional, Badan Pengkajian dan Pengembangan Kebijakan, Kementerian Luar Negeri Republik Indonesia (2016) tertulis, untuk mendukung kebijakan diplomasi pertahanan maritim melalui kerjasama multilateral, Indonesia dan beberapa negara di Asia mendirikan forum bernama HACGAM ( Head of Asian Coast Guard Meeting) yang merupakan pertemuan tahunan bagi institusi-institusi yang menjalankan fungsi Coast Guard. Pada bulan Mei 2016 Indonesia menjadi tuan rumah untuk pertemuan coast guards dari 20 negara di Asia, dan pertemuan tersebut memfokuskan pada upaya peningkatan information sharing dan pembangunan kapasitas coast guard dalam mengantisipasi keamanan maritim di Asia.

Ketiga adalah Diplomasi Pertahanan Maritim Hukum Internasional. Diplomasi pertahanan beroperasi dalam kerangka hukum internasional, peraturan dan adat istiadat yang berlaku, baik dalam diplomasi maupun hukum nasional yang kemudian membentuk solusi struktural tertentu, mendefinisikan prinsip-prinsip kerja sama dengan lembaga negara lainnya, terutama dengan Kementerian Luar Negeri, serta menetapkan tujuan dan tugas (Drab, 2018). Penerapan kebijakan diplomasi ini mengacu pada hukum internasional yang mengatur mengenai hukum dalam laut atau United Nation Convention on the Law of the Sea (UNCLOS). Upaya diplomasi pertahanan maritim dalam sengketa Laut Natuna Utara, Pemerintah Indonesia selalu mengingatkan Tiongkok dan negara lain yang berusaha memasuki wilayah kedaulatan Indonesia tanpa izin dengan mengacu pada peraturan UNCLOS 1982. Pasal 49 UNCLOS 1982 ayat 1 dan 4 mengatakan

The sovereignty of an archipelagic State extends to the waters enclosed by the archipelagic baselines drawn in accordance with article 47, described as archipelagic waters, regardless of their depth or distance from the coast. (UNCLOS, 1982. Pasal 49, Ayat 1)

dan,

The regime of archipelagic sea lanes passage established in this Part shall not in other respects affect the status of the archipelagic waters, including the sea lanes, or the exercise by the archipelagic State of its sovereignty over such waters and their air space, bed and subsoil, and the resources contained therein. (UNCLOS, 1982. Pasal 49, Ayat 4)

Pemerintah Indonesia melalui Menteri Luar Negeri sudah melakukan beberapa upaya diplomasi dalam bentuk peringatan hingga dalam konferensi internasional terkait batas wilayah Natuna Utara. Pada bulan Januari 2020, memperingatkan Tiongkok untuk patuhi wilayah ZEE sesuai dengan UNCLOS 1982 (Kompas, 2020). Peringatan dan protes tersebut dilakukan pasca terjadinya lagi pelanggaran yang dilakukan 
kapal Tiongkok yang memasuki wilayah ZEE Indonesia di perairan Natuna dengan memanggil Duta Besar Tiongkok di Indonesia. Tiongkok merupakan salah satu bagian dari UNCLOS 1982, sudah seharusnya mematuhi dan menghormati peraturan yang ada di UNCLOS 1982 (Muhaimin, 2020). Upaya yang dilakukan Pemerintah Indonesia baik dari latian bersama, patroli gabungan, peningkatan kerjasama pertahanan, dan peringatan terkait UNCLOS 1982 bukan merupakan peningkatan ketegangan di perbatasan Laut Natuna Utara, melainkan bentuk dari diplomasi pertahanan maritim Indonesia.

Apabila dikaji menggunakan narrative policy analysis, dengan elemen naratif kebijakan yang terdiri dari karakter, plot, dan policy solution apabila dikaitkan dengan kebijakan diplomasi pertahanan maritim maka karakter pahlawan (hero) dalam kebijakan ini adalah UNCLOS 1982 karena peraturan tersebut hingga saat ini masih digunakan dalam hukum internasional terutama Indonesia dan Tiongkok berada didalam kesepakatan hukum tersebut, dan negara lain melalui kontrak kerjasama diplomasi. Karakter penjahat (villain) dalam kebijakan ini adalah Tiongkok dan negara-negara lain yang berusaha mengganggu kedaulatan wilayah Indonesia dengan masuknya kapal-kapal asing penangkap ikannya secara illegal di wilayah Laut Natuna Utara. Selanjutnya karakter korban (victim) dari kebijakan ini adalah Pemerintah Indonesia yang di dalamnya terdapat Kementerian Luar Negeri, Kementerian Pertahanan, TNI, dan Bakamla karena mereka yang dirugikan akibat adanya pelanggaran yang dilakukan oleh negara lain melalui kapalkapal penangkap ikannya. Terdapat banyak tantangan ke depan dalam kebijakan diplomasi pertahanan maritim yang dilakukan Indonesia. Hal tersebut akan dipaparkan pada bagian selanjutnya dengan perspektif narrative policy analysis dalam elemen naratif kebijakan policy solution mengenai tantangan dan solusi dari kebijakan diplomasi pertahanan maritim Indonesia dalam penyelesaian konflik di Laut Natuna Utara.

\section{Tantangan Kebijakan Diplomasi Pertahanan Maritim dalam Konflik Laut Natuna Utara}

Kerasnya penolakan Tiongkok terhadap aturan perbatasan Indonesia menjadi tantangan tersendiri bagi Pemerintah Indonesia terutama kebijakan One Belt One Road (OBOR) Tiongkok. OBOR merupakan proyek konektivitas ambisius Tiongkok melalui pembangunan infrastruktur dan jalur transportasi darat dan laut yang menghubungkan negaranya dengan kawasan Asia, Eropa, dan Afrika yang menciptakan efek borderless bagi setiap negara yang dilaluinya. Pertumbuhan kekuatan Tiongkok merupakan aspek yang paling menonjol dari perubahan strategis yang sedang berlangsung di Asia Tenggara. Sengketa maritim semakin menjadi tantangan yang signifikan bagi keamanan kawasan kedaulatan Indonesia. Kebijakan One Belt One Road (OBOR) serta nine dash line Tiongkok menjadi tantangan tersendiri bagi Pemerintah Indonesia untuk menjaga kedaulatan wilayah melalui Diplomasi Pertahanan Maritim (Wibawati, Sari, dan Sulistyani, 2018). Meskipun Indonesia secara resmi merupakan negara non-penggugat, namun Indonesia menolak klaim nine dash line menurut sejarah Tiongkok atas Laut Tiongkok Selatan. 
Saat menjadi perantara negosiasi antara ibu kota ASEAN dan Beijing untuk kode etik regional, pejabat pertahanan Indonesia telah berulang kali menyatakan keprihatinannya atas kerentanan kedaulatan teritorial negara Indonesia terhadap perambahan Tiongkok menggunakan armada penangkapan ikannya (Gindarsah, 2015). Selain itu tantangan lain yang harus menjadi perhatian Pemerintah Indonesia dalam menjaga wilayah kedaulatan di Laut Natuna Utara adalah aktivitas pengerukan laut dan pembentukan pulau buatan berpotensi mengubah perimbangan kekuatan militer di di Laut Tiongkok Selatan dengan membangun infrastruktur strategis seperti landasan terbang, dermaga dan sistem intai maritim di pulaupulau buatan tersebut, Tiongkok dapat mengendalikan seluruh navigasi yang melewati Kepulauan Spratly (Laksmana, Gindarsah, Mantong, 2018).

Dalam ASEAN sendiri melalui ADMM+, telah menunjukkan kurangnya tindakan yang terkoordinasi dan kolektif, sebagian karena norma "non-interferensi" yang diterima dan "pembangunan konsensus" yang menghalangi tindakan tersebut (Chang, 2016). Adanya diplomasi pertahanan maritim juga menunjukkan ke arah persamaan yang positif seperti sebagaimana membangun langkah-langkah kepercayaan dalam diplomasi, bukan kepada persaingan yang kompetitif antar negara. Namun dapat dikatakan bersaing dan kompetitif jika perjanjian pertahanan yang disepakati adalah untuk memperkuat persaingan dan menunjukkan keunggulan satu dengan lainnya.

Tantangan lain dalam penerapan kebijakan Diplomasi pertahanan maritim muncul dari internal Pemerintahan Indonesia. Dalam melaksanakan diplomasi, komunikasi dan koordinasi dengan berbagai instansi terkait khususnya Kementerian Luar Negeri sebagai leading sector diplomasi negara tidak dapat dihindari mengingat salah satu fungsi Kementerian Luar Negeri adalah melaksanakan kebijakan di bidang hubungan luar negeri (Sudarsono, Mahroza, \& Surryanto, 2018). Namun koordinasi antara Kementerian Luar Negeri, Kementerian Pertahanan, TNI, dan Bakamla dalam hal penyiapan strategi diplomasi pertahanan maritim belum berjalan dengan baik, meskipun komunikasi antar personel dari instansi-instansi tersebut berjalan intens (RRI, 2020). Komunikasi yang terjalin antar instansi tersebut hanya sebatas urusan operasional, sedangkan pada tingkat kebijakan hampir tidak ada terutama yang berkaitan dengan penyusunan strategi diplomatic.

Bentuk dari kurangnya koordinasi dalam penerapan kebijakan diplomasi pertahanan maritim seperti kebingungan yang ada pada pertanyaan sejauh mana kewenangan Angkatan Laut berlaku dalam pengamanan perairan Indonesia pasca pembentukan Badan Keamanan Laut (Bakamla) melalui Peraturan Presiden Nomor 178 Tahun 2014 yang sementara itu dianggap belum bisa mengurai secara baik tata kelembagaan serta pembagian wewenang untuk pengamanan perairan Indonesia (Laksmana, Gindarsah, Mantong, 2018). Tumpang tindih operasional kebijakan dipastikan akan terjadi dalam penerapannya. Padahal konsep diplomasi pertahanan maritim memerlukan integrasi dan perpaduan antar sectoral dalam pengelolaan ranah maritim baik dari segi pertahanan, keamanan, dan diplomasi. Selain itu, Alasan utama 
yang menyebabkan tidak efektifnya kerja sama antara TNI dan Kementerian Luar Negeri dalam merumuskan strategi diplomasi adalah belum adanya white paper kebijakan diplomatik yang dapat dijadikan acuan di tingkat nasional (Sudarsono, Mahroza, \& Surryanto, 2018).

Selanjutnya cakupan kerja sama bilateral dan multilateral Indonesia masih berfokus terhadap beberapa negara saja seperti Malaysia, Filipina, Singapura, Jepang, dan Amerika Serikat. Sedangkan dalam sengketa Laut Natuna Utara, negara yang menjadi actor utama adalah Tiongkok dan Vietnam yang sering mengganggu wilayah perbatasan. Pada dua bulan berturut-turut yaitu September-Oktober 2020, Pemerintah Indonesia menangkap dua kapal asing Vietnam yang memasuki wilayah Natuna Utara. Bulan September 2020 KRI Usman Harun-359 menangkap dua Kapal Ikan Asing (KIA) asal Vietnam saat melakukan pencurian ikan atau illegal fishing di Laut Natuna Utara (Kompas, 2020). Selanjutnya bulan Oktober 2020, Kapal Perang RI John Lie-358 milik TNI Angkatan Laut (AL) menangkap kapal pencuri ikan berbendera Vietnam di Laut Natuna Utara (Kompas, 2020). Melihat kondisi tersebut, tantangan terhadap konsistensi dan perluasan kerja sama pertahanan maritim di perbatasan Laut Natuna Utara sangat diperlukan sehingga kepentingan Indonesia dan kepentingan negara lain yang terlibat dapat terkakomodasi. Mengingat strategi Diplomasi Pertahanan Maritim yang menyeluruh diperlukan juga investasi yang menyeluruh. Sehingga negara lain yang berada dalam wilayah maritim Indonesia dapat memperhatikan secara serius tentang wilayah kedaulatan Indonesia.

Dari segi hukum internasional sebenarnya klaim Tiongkok dalam nine dash line bukan merupakan ancaman bagi Indonesia, karena menurut hukum internasional tidak sesuai dengan yang tertera di dalamnya. Menurut Sidjabat, Octavian, \& Said (2018), Indonesia dan Tiongkok adalah dua diantara negaranegara yang meratifikasi UNCLOS, sehingga apabila ada sengketa di antara dua negara, rujukan utamanya adalah UNCLOS dan bukan argumen lain seperti Traditional Fishing Zone yang tidak sesuai dengan Hukum Internasional. Namun yang menjadi tantangan adalah diplomasi pertahanan maritim hukum internasional dari Indonesia selalu tidak digubris oleh Tiongkok. Walaupun Indonesia tidak mengakui klaim nine dash line dan Indonesia juga bukan merupakan claimant states, namun provokasi dari Pemerintah Tiongkok masih terus dilakukan melalui kapal-kapal nelayannya yang sering masuk wilayah yurisdiksi Indonesia dengan dikawal kapal Coast Guard Tiongkok.

Secara keseluruhan, penerapan kebijakan diplomasi pertahanan maritime yang dilakukan Pemerintah Indonesia masih belum maksimal. Dimulai dari penerapan kebijakan OBOR dan klaim Tiongkok atas nine dash line yang menciptakan efek borderless sehingga mempengaruhi wilayah kedaulatan Indonesia, pengerukan hingga pembentukan pulau oleh Tiongkok di wilayah perbatasan Laut Natuna Utara juga menjadi bentuk tantangan langsung di wilayah perbatasan karena memudahkan Tiongkok mengendalikan seluruh navigasi yang melewati Kepulauan Spratly. Tiongkok juga tidak merujuk pada hukum UNCLOS terkait Zona Ekonomi Eksklusif dalam kebijakan luar negerinya. Kemudian dari sisi internal 
Jurnal Studi Diplomasi dan Keamanan, Volume 13. No 1, January 2021.

Pemerintah Indonesia tantangan yang muncul adalah kurangnya koordinasi dan komunikasi antar instansi terkait yang menangani permasalahan konflik di Laut Natuna Utara. Kementerian Luar Negeri, Kementerian Pertahanan, TNI, dan Bakamla masih berjalan sendiri-sendiri dalam penerapan kebijakan diplomasi pertahanan maritimnya. Selain itu, cakupan kerja sama bilateral dan multilateral Pemerintah Indonesia hanya dilakukan dengan negara-negara yang tidak terlibat konflik secara langsung di wilayah perairan Laut Natuna Utara.

\section{SIMPULAN}

Kedaulatan teritorial Indonesia harus menjadi kepentingan utama dan vital dalam menentukkan kebijakan luar negeri dan pertahanan. Sengketa kasus Laut Natuna Utara yang masih berjalan hingga saat ini dan mungkin akan terus berlanjut ke depan dapat menjadi pertimbangan kebijakan kawasan karena bersinggungan langsung dengan kepentingan utama tersebut. Maka dari itu, Pemerintah Indonesia menerapkan kebijakan Diplomasi pertahanan maritim. Diplomasi pertahanan maritim Indonesia menerapkan beberapa pola yang dilakukan, yaitu: Diplomasi Pertahanan Maritim Bilateral, Diplomasi Pertahanan Maritim Multilateral, dan Diplomasi Pertahanan Maritim Hukum Internasional. Ketiga pola kebijakan tersebut dianggap efektif dalam mengatasi sengketa Laut Natuna Utara dengan metode soft defense.

Namun penerapan kebijakan diplomasi pertahanan maritim dalam penanganan sengketa laut natuna utara mendapatkan beberapa tantangan. Penulis menemukan ada tiga tantangan yang ada dalam penerapan kebijakan tersebut. Tantangan yang pertama adalah Perlunya leading actor yang konsisten dalam pemerintah yang bertanggung jawab secara jelas mengatur kebijakan diplomasi pertahanan maritim. Tantangan yang kedua adalah perluasan cakupan kerjasama bilateral dan multilateral dalam diplomasi pertahanan maritim. Tantangan yang ketiga adalah, ketidakpercayaan dan penentangan Tiongkok dalam aturan hukum internasional UNCLOS 1982 dengan menerapkan klaim nine dash line.

Elemen naratif policy solution dalam kebijakan diplomasi pertahanan maritim yang perlu dilakukan Indonesia untuk menghadapi tantangan tersebut antara lain, Pertama ciptakan hubungan kerja sama diplomasi pertahanan maritim dengan melibatkan negara-negara yang terlibat langsung dalam konflik Laut Natuna Utara. Kerja sama tersebut mampu untuk mengurangi beberapa program-program yang tidak menawarkan manfaat yang jelas, dimana mengakibatkan banyak sumber daya yang terbuang terkait keamanan wilayah kedaulatan Indonesia. Kedua, fokus program pada kegiatan yang menawarkan manfaat konkret bagi negara-negara yang berbatasan langsung dengan Laut Natuna Utara. Pertukaran terkait pertahanan harus tetap dilanjutkan. Ketiga, sipil harus dilibatkan dalam pelaksanaan kegiatan diplomasi pertahanan maritim untuk membentuk badan konsultasi politik-militer yang mampu mengintegrasikan 
dengan negara-negara lain. Keempat, perlunya koordinasi terpusat antara Kementerian Pertahanan, Kementerian Luar Negeri, Bakamla, dan TNI. Hal tersebut diperlukan supaya tidak terjadi miss leading antar lembaga, yang mana diplomasi pertahanan maritim membutuhkan koordinasi yang lebih besar dan kuat. Buku putih mengenai kebijakan diplomasi menjadi penting untuk dimiliki oleh Kementerian Luar Negeri karena akan menjadi acuan utama penyusunan strategi diplomasi oleh instansi pemerintah yang membidangi urusan diplomatik. Sehingga diplomasi pertahanan maritim lebih terintegrasi dengan kebijakan luar negeri, keamanan, dan ekonomi. Berdasarkan hal tersebut Pemerintah Indonesia perlu mempertimbangkan kembali terkait kebijakan diplomasi pertahanan maritimnya karena perkembangan geopolitik dunia yang selalu berubah-ubah. Sehingga wilayah terluar Indonesia tidak mudah di klaim oleh negara manapun, karena berkaitan erat dengan kedaulatan wilayah negara Republik Indonesia.

\section{DAFTAR PUSTAKA}

\section{Jurnal}

Bisley, Nick. (2014). The Possibilities and Limits of Defence Diplomacy in Asia. ANU Strategic and Defence Studies Centre. Centre of Gravity Series paper \#17.

Blaxland, John. (2014). Defending Defence Diplomacy. ANU Strategic and Defence Studies Centre. Centre of Gravity Series paper \#17.

Butler, Colin J. (2005). Strategic Alliance UK. Journal Strategic Change 14.

Chang, Jun Yan. (2016). Defence Diplomacy in ASEAN. The Habibie Centre in Thinking ASEAN, Issue 17.

Charillon, F., Balzacq, T., Ramel, F. (2020). Defense Diplomacy dalam Global Diplomacy: An Introduction to Theory and Practice. The Sciences Po Series in International Relations and Political Economy.

Drab, Lech. (2018). Defence Diplomacy-An Important Tool For the Implementation of Foreign Policy and Security of the State. Poland. War Studies University.

Fathun, Laode Muhammad. (2019). ASEAN Contemporary Security: Maritime Diplomacy in Handling of Maritime Security Threats in Malaka Straits. Insignia Journal of International Relations Vol 6, No 1.

Fearon, J. D. (2002). Domestic Politics, Foreign Policy, and Theories of International Relations. Annual Review of Political Science.

Gilang P, M Harviend. (2016). Peran ASEAN Defence Ministers Meeting Plus (ADMM Plus) Sebagai Forum Diplomasi Pertahanan di Kawasan Asia. Jurnal Studi Diplomasi dan Keamanan Vol 8, No 2.

Gindarsah, Iis. (2015). Indonesia's Defence Diplomacy: Harnessing the Hedging Strategy Against Regional Uncertainties. The RSIS Working Paper. 
Jones, Michael D., McBeth, Mark K. (2010). A Narrative Policy Framework: Clear Enough to Be Wrong?. The Policy Studies Journal, Vol. 38, No. 2.

Kusuma, Wida Sanditya., Halkis, Mhd., Yusgiantoro, Purnomo. (2019). Diplomasi Pertahanan Indonesia Terhadap Pelanggaran Wilayah oleh China di Perairan Kepulauan Natuna Melalui Pelaksanaan Latihan Puncak Angkasa Yudha TNI AU Tahun 2016. Jurnal Diplomasi Pertahanan Volume 5, Nomor 3.

Laksmana, Evan A., Gindarsah, Iis., Mantong, Andrew W. (2018). Menerjemahkan Visi Poros Maritim Global ke Dalam kerangka Diplomasi Pertahanan Maritim Dalam Kebijakan Luar Negeri Indonesia di Era Jokowi. Centre for Strategic and International Studies, Jakarta.

Manowong, Ektewan., Ocha, Witchayanee. (2017). Defence Diplomacy and ASEAN Community Integration: Opportunities and Challenges. APHEIT JOURNAL Volume 6 Number 1.

Medeiros, Sabrina Evangelista., Moreira, William de Sousa. (2017). Maritime Co-operation among South Atlantic Countries and Repercussions for the Regional Community of Security Practice. Contexto Internacional vol. 39.

Midhio, I Wayan., Priyono, Juniawan. (2019). Education and Research as Components of Indonesia Defense Diplomacy. Jurnal Pertahanan Vol 5, No 1.

Muhaimin, Ramdhan. (2018). Kebijakan Sekuritisasi dan Persepsi Ancaman di Laut Natuna Utara. Politica Vol. 9 No. 1.

Mundayat, Aris Arif., Widodo, Pujo., Prakasa, Bayu. (2018). Diplomasi Pertahanan Indonesia dalam Mewujudkan Poros Maritim Dunia. Jurnal Prodi Diplomasi Pertahanan, Vol 4, No 2.

Nugraha, Muhammad HR., Sudirman, Arifin. (2016). Maritime diplomacy Sebagai Strategi Pembangunan Keamanan Maritim Indonesia. Jurnal Wacana Politik, Vol 1, No 2. 175-182.

Pedrason, Rodon., Kurniawan, Yandry., Purwasandi, Purwasandi. 2016. Handling of Illegal, Unreported and Unregulated (IUU) Fishing. Jurnal Pertahanan Vol. 2 No. 1.

Poespojoedho, R Wing WItjahyo O W. (2019). Naval diplomacy: Upaya defensive Indonesia dalam Konflik Laut Tiongkok Selatan di Era Joko Widodo. Jurnal Hubungan Internasional. Tahun XII No 2.

Sambogo, Alief. (2018). Penamaan Laut Natuna Utara Oleh Pemerintah Indonesia dalam Perspektif Hukum Internasional. Jurist-Diction: Vol 1, No 2.

Saragih, Hendra Maujana. (2018). Diplomasi Pertahanan Indonesia dalam Konflik Laut China Selatan. Jurnal Ilmu Politik dan Komunikasi, Volume VIII No 1.

Shanahan, Elizabeth A., Jones, Michael D., McBeth, Mark K. (2017). How to conduct a Narrative Policy Framework study. The Social Science Journal. 
Sidjabat, Christine A., Octavian, Amarulla., Said, Budiman Djoko. (2018). Sinergi Instrumen Kekuatan Maritim Indonesia Menghadapi Klaim China atas Laut China Selatan. Jurnal Pertahanan \& Bela Negara, Volume 8 Nomor 2.

Sudarsono, Budyanto Putro., Mahroza, Jonni., Surryanto, D.W. (2018). Indonesia Defense Diplomacy in Achieving National Interest. Journal of Defense \& State Defense, Volume 8 Number 3.

Tan, See Seng. (2014). Digging in its backyard: Why Australia Should Deepen Engagement with Southeast Asia. ANU Strategic and Defence Studies Centre. Centre of Gravity Series paper \#17.

Taylor, Brendan. (2014). Australia's Defence Diplomacy: Time for a Stocktake. ANU Strategic and Defence Studies Centre. Centre of Gravity Series paper \#17.

The Strategic Survey. (2019). New Challenges to Defence Diplomacy dalam Strategic Survey 100. Routledge Publisher.

Wibawati, Santi Wira., Sari, Marina Ika., Sulistyani, Yuli Ari. (2018). Potensi Tantangan One Belt One Road (OBOR) Bagi Kepentingan Nasional Indonesia di Bidang Maritim. Jurnal Kajian Wilayah 9. 109-123.

Winger, Gregory. (2014). The Velvet Gauntlet: A Theory of Defense Diplomacy. IWM Junior Visiting Fellows' Conferences Vol 33.

\section{Buku}

Centre for Strategic and International Studies. (2017). Diplomasi Pertahanan Maritim: Strategi, Tantangan, dan Prospek. Badan Pengkajian dan Pengembangan Kebijakan, Kementerian Luar Negeri Republik Indonesia.

Cresswell, John W. (2014). Research Design Pendekatan Kualitatif Kuantitatif dan Mixed, terj. Achmad Fawaid. Yogyakarta: Pustaka Pelajar. hal 4-5.

Cassidy, Fikry., Samosir P.J.P., Oktarossa, Debbi., Prasetyo, Erry W., Nugroho, Faiz A., Fitri, Widya., Putro, Robertus A.P. (2016). Diplomasi Poros Maritim: Keamanan Maritim dalam Perspektif Politik Luar Negeri. Badan Pengkajian dan Pengembangan Kebijakan, Kementerian Luar Negeri Republik Indonesia.

Dunn, William N. (1999). Pengantar Analisis Kebijakan Publik. Yogyakarta: Gajah. Mada University Press.

Kementerian Pertahanan. (2015). Buku Putih Pertahanan Indonesia.

Marbun. (2007). Kamus Politik. Jakarta: Pustaka Sinar harapan.

Sugiyono. (2012). Memahami Penelitian Kualitatif. Bandung : ALFABETA.

\section{Website dan Media Online}


Kementerian Pertahanan. (2017). Indonesia, Malaysia, dan Filipina Resmi Mulai Kerja Sama Patroli Maritim Terkoordinasi. < https://bit.ly/38rbFTi > Diakses pada 25 Oktober 2020.

Kementerian Pertahanan. (2020). Indonesia - Australia Sepakati Kerjasama Keamanan Maritim. < https://bit.ly/2I1srNM > Diakses pada 25 Oktober 2020.

Kompas. (2020). Dua Kapal Ikan Asing Vietnam di Laut Natuna Utara Kembali Ditangkap. < https://bit.ly/38fdVNE > Diakses pada 25 Oktober 2020.

Kompas. (2020). KRI John Lie Tangkap Kapal Pencuri Ikan Asal Vietnam di Natuna. < https://bit.ly/34WvU9s > Diakses pada 25 Oktober 2020.

Kompas. (2020). Saat TNI AL dan Jepang Pamer Armada di Laut Natuna Utara. < https://bit.ly/36lv1H5 > Diakses pada 25 Oktober 2020

Kompas. (2020). Soal Natuna, Menlu Retno Minta China Patuhi Wilayah ZEE Sesuai UNCLOS 1982. < https://bit.ly/3euC3wQ > Diakses pada 25 Oktober 2020.

Lowy Institute. (2020). Indonesia Laut Cina Selatan Berjalan Sendiri. < https://bit.ly/32icc6m > Diakses pada 25 Oktober 2020.

Mabes TNI. (2018). Koarmada II Tuan Rumah Sidang Ketua Komite Perbatasan RI-RPBC Tahun $2018<$ https://bit.ly/3pc0P9P > Diakses pada 25 Oktober 2020.

Mabes TNI. (2020). Panglima TNI: Forum ACDFM Ke-17 Pentingnya Memperkuat Kerja Sama Militer ASEAN. $<$ https://bit.ly/38e37Py > Diakses pada 25 Oktober 2020.

Reuters. (2017). Asserting sovereignty, Indonesia renames part of South China Sea. <https://reut.rs/36rr5FX $>$ Diakses pada 1 Desember 2020.

RRI. (2020). Pemerintah Kurang Koordinasi Tangani Masalah Zona Ekonomi Eksklusif Natuna. < https://bit.ly/3pTurcw > Diakses 23 November 2020. 